\title{
Cold tolerance evaluation of temperate rice (Oryza sativa L. ssp. japonica) genotypes at seedling stage
}

\section{Evaluación de la tolerancia al frío en genotipos de arroz templado (Oryza sativa L. ssp. japonica) en estado de plántula}

\author{
Gabriel Donoso $^{1 *}$, Patricia Cabas $^{1}$, Mario Paredes $^{1}$, Viviana Becerra $^{1}$ \& Mónica BalzarinI ${ }^{2}$ \\ 'Laboratorio de Biotecnología, Instituto de Investigaciones Agropecuarias (INIA), Avenida Vicente Méndez 515, \\ Chillán, Chile. \\ ${ }^{2}$ Universidad Nacional de Córdoba, Avenida Enrique Barros esq. Los Nogales, Ciudad Universitaria, CP: 5000, \\ Córdoba, Argentina. \\ *gabriel.donoso@inia.cl
}

\begin{abstract}
Cold is the most important abiotic factor that affect rice yield in Chile, which can alter the phenology and physiology of the rice at seedling stage. With the aim to increase the accuracy for cold tolerance evaluation in Chilean Rice Breeding Program of the Instituto de Investigaciones Agropecuarias (INIA), 109 experimental lines were evaluated to cold tolerance using morphological and physiological traits, at seedling stage. Cold treatment was achieved by placing seedlings at $5{ }^{\circ} \mathrm{C}$ on dark for $72 \mathrm{~h}$ and evaluations were made after seven days recovery. Leaf chlorosis based on the standard evaluation system scale (SES), Chlorophyll content (Chl), Malondialdehyde concentration (MDA) and maximum quantum yield of Photosystem II (Fv/Fm) were evaluated. Best linear unbiased prediction (BLUP) for all traits and multivariate analysis were made in order to determine the cold tolerant genotypes. Variability in cold tolerance among experimental lines was described by principal component and cluster analysis of BLUPs for all traits. The broad sense heritability calculated for SES scale was the highest (0.54), while for Fv/Fm was the lowest (0.10). Genotypes with high cold tolerance were Quila 242002 and Quila 241304, while more susceptible genotypes were Quila 64117, Quila 260312 and Quila 241607. The results suggest that the BLUPs and multivariate analysis allow adequate clustering of rice genotypes according to the degree of their cold tolerance. Finally, we suggest that SES scale and Chl content were the most suitable traits to evaluate cold tolerance for the rice genotypes studied and for the conditions evaluated.
\end{abstract}

KEYwords: Experimental lines, low temperatures, multivariate analysis, BLUP.

\section{RESUMEN}

El frío es el factor abiótico más importante que afecta los rendimientos del arroz en Chile, el cual puede alterar la fenología y la fisiología del arroz en estado de plántula. Con el objetivo de incrementar la precisión en la evaluación por tolerancia al frío en el Programa de Mejoramiento Genético de arroz del Instituto de Investigaciones Agropecuarias (INIA) de Chile, se evaluó la tolerancia al frío de 109 líneas experimentales en estado de plántula, utilizando atributos morfológicos y fisiológicos. El tratamiento por frío fue realizado sometiendo las plántulas a $5{ }^{\circ} \mathrm{C}$ por $72 \mathrm{~h}$ y las evaluaciones fueron realizadas después de siete días de recuperación. Se evaluó la clorosis foliar según la escala del sistema de evaluación estándar del IRRI (SES), el contenido de clorofila (Chl), la concentración de malondialdehido (MDA) y la eficiencia máxima fotoquímica del fotosistema II (Fv/Fm). El mejor predictor lineal insesgado (BLUP) para todos los atributos y un análisis multivariado fueron realizados con el fin de determinar los genotipos tolerantes al frío. La variabilidad de la tolerancia al frío entre las líneas experimentales fue descrita mediante componentes principales y un análisis de conglomerado utilizando los BLUPs para cada atributo. La heredabilidad en sentido amplio calculada para la escala SES fue la mayor $(0,54)$, mientras que para Fv/Fm fue la menor $(0,10)$. Quila 242002 y Quila 241304 fueron los genotipos con mayor tolerancia al frío, mientras que los genotipos con mayor susceptibilidad fueron Quila 64117, Quila 260312 y Quila 241607. Los resultados sugieren que los BLUPs y el análisis multivariado permiten un adecuado agrupamiento de los genotipos según el grado de su tolerancia al frío. Finalmente, sugerimos que la escala SES y el contenido de Chl fueron los atributos más adecuados para evaluar la tolerancia al frío en los genotipos de arroz estudiados en las condiciones evaluadas.

Palabras clave: Líneas experimentales, bajas temperaturas, análisis multivariado, BLUP.

\section{INTRODUCTION}

Low temperatures is one of the main limiting factors for crop yield in the world (Sanghera et al. 2011). In the case of rice (Oryza sativa L.) in Chile, cold is the most important abiotic factor that affects rice production (Alvarado \& Grau 1991). In this country, is growing between the Maule $\left(35^{\circ}\right.$ $\mathrm{S}$ lat) to Biobío Region ( $36^{\circ} \mathrm{S}$ lat), being one of the most southern countries of the world where rice is cultivated. In 30 years of temperature data from Chile, the mean of minimum 
temperatures during the seedling stage ranged between $5{ }^{\circ} \mathrm{C}$ to $7{ }^{\circ} \mathrm{C}$ (Alvarado \& Hernaiz 2007). Also, in a cold year for rice in Chile (2009), the minimal temperatures can achieve up to below $5^{\circ} \mathrm{C}$ by six consecutive days.

In general, rice is susceptible to temperatures below 15 ${ }^{\circ} \mathrm{C}$ (Howarth \& Ougham 1993; Fujino et al. 2004). The effects of low temperatures on the crop depend on the development stage, intensity, and exposure time (Díaz et al. 2006). Exposure to low temperatures causes physiological changes to the crop (De los Reyes et al. 2003, Aghaee et al. 2011) such as decrease in total chlorophyll content (Aghaee et al. 2011), inhibition of photosynthetic activity (Allen \& Ort 2001, Díaz et al. 2006, Suzuki et al. 2008), and oxidative stress. Low temperatures at vegetative stage affect seedling vigor, which leads to nonuniform plant height (Da Cruz et al. 2006). Furthermore, there is irreversible injury in leaves, such as necrosis, mottled chlorosis (Suzuki et al. 2008, Ye et al. 2009), and chlorosis (Andaya \& Mackill 2003). Leaf damage caused by low temperatures at vegetative stage can be evaluated by visual ranking through the SES for rice of the International Rice Research Institute (IRRI). The screening of genotypes for cold-tolerance based on visual scale has been widely accepted (Da Cruz et al. 2013). However, these methodologies can have some limitations because depend on subjectivity of evaluator (Kim \& Tai 2011). Accordingly, is necessary to find objective methodology for cold tolerance evaluations at seedling stage. Many research have shown diverse traits for evaluate cold tolerance in rice at vegetative stage. For example, chlorophyll content is a good estimator of chlorosis in rice plant (Yoshida 1981) and gives a more accurate evaluation than the visual analysis (Park et al. 2013). Regarding cold stress damage in plants, some evaluations of oxidative damage has been performed (Kim \& Tai 2011, Zhang et al. 2011, Kim et al. 2012). Oxidative damage can be indirectly evaluated by malondialdehyde content measurement, which is considered as a marker of cold damage (Campos et al. 2003, Kim \& Tai 2011). Another widely used tool to measure photosynthetic activity and stress signal in plants is chlorophyll fluorescence (Sikuku et al. 2010).

Multivariate analysis and best linear unbiased prediction play a key role in genotype selection. Multivariate analysis is a good tool for identification of the best performance genotypes for the interest trait (Bosetti et al. 2012), because this analysis summarize the information from several traits into a reduced set of variables. On the other hand, BLUP is a method of statistical analysis for estimate random-effects based in a mixed-model (Piepho et al. 2008). One of the most important characteristic of BLUP is shrinkage to the mean, which improved the estimates of means of traits increasing accuracy (Hill \& Rosenberger 1985, Piepho et al. 2008). BLUP values for traits have showed a good predictive accuracy compared with other methodologies (Piepho et al. 2008). Despite their usefulness for phenotypic selection, BLUP selection has been underutilized by plant breeders (Heffner et al. 2009). Nowadays, there are some cold-tolerant rice cultivars that can grow under cold climates such as in Australia, Japan, China (Yoshida 1981), and Chile (Alvarado \& Hernaiz 2007). Chile's Instituto de Investigaciones Agropecuarias (INIA) Rice Breeding Program has developed more than 4000 experimental lines with high potential for cold tolerance at the seedling stage. However, the quantitative genetic basis of cold tolerance at seedling stages has been low studied (Da Cruz et al. 2010). Therefore, the aim of this study was to increase the accuracy for cold-tolerance selection in rice from Chile's INIA Breeding Program at the seedling stage. For this, phenotypic selection for cold tolerance was made using BLUPs and multivariate analysis.

\section{MATERIALS AND METHODS}

Plant material

Seeds from 109 rice experimental lines of the INIA Quilamapu Rice Breeding Program were evaluated. The Colombian variety Oryzica 1 was used as a cold-susceptible control (Torres \& Geraldi 2007) and the Chilean variety Ambar-INIA was used as cold-tolerant control.

\section{GROWTH CONDITIONS}

The study was made in INIA Quilamapu in the Biobío Region $\left(36^{\circ} 35^{\prime} \mathrm{S} ; 7^{\circ} 05^{\prime} \mathrm{W}\right)$, Chillán, Chile. The cold tolerance evaluation was performed similarly as previous studies in rice (Andaya \& Mackill 2003, Andaya \& Tai 2006, Koseki et al. 2010) with some modifications. Seeds from each genotype were sown in $500 \mathrm{ml}$ plastic pots with clay soil (Vertisol) previously fertilized with NPK (0.2 g urea, $0.09 \mathrm{~g}$ triple superphosphate, and $0.11 \mathrm{~g}$ potassium muriate) and a water depth of $5 \mathrm{~cm}$. Germination and initial growth took place in a greenhouse at $28 \pm 1{ }^{\circ} \mathrm{C}$ and $200 \mu \mathrm{mol}$ photons $\mathrm{m}^{-2} \mathrm{~s}^{-1}$. Seedlings with one to two leaves, 12 days after sowing, were transferred to field conditions under a $60 \%$ raschel mesh (AGRI 70, Arrigoni) for nine days for acclimation to field conditions from January 1st to 9 th, 2014. After, plants were grown under 36\% raschel mesh (AGRI 50, Arrigoni) for 12 days, to reduce the wind effect, from January 10th to 22nd, 2014. Seedlings with three to four totally expanded leaves were placed in a cold chamber at continuous $5 \pm 0.4{ }^{\circ} \mathrm{C}$ under completely dark for $72 \mathrm{~h}$ (Koseki et al. 2010). Afterward, seedlings were exposed to field conditions under 36\% raschel mesh (AGRI 50, Arrigoni) for seven days and leaf samples were taken, from January 26th to February 1st, 2014. Temperature and rainfall data were logged when experiment were conducted under field conditions (Fig. 1). All the leaves of three plants from every pot were frozen in liquid nitrogen and stored at $-80^{\circ} \mathrm{C}$. The experimental design was a randomized complete block with 3 replicates corresponding to three individual pots. Rice plants with similar appearance into the plastic pot were evaluated.

LEAF CHLOROSIS

Leaf chlorosis was evaluated seven days after cold 
treatment based on SES scale from IRRI (2009) with some modifications. The evaluation scale ranges from 1 to 9 based mainly on changes in leaf coloration as follows: dark green leaf (value 1), dark green seedlings with brown or yellow tips (value 2), light green seedlings (value 3), light green seedlings with brown or yellow leaves (value 4), yellow seedlings (value 5), yellow seedlings with brown leaves (value 6), brown seedlings (value 7), brown seedlings with dry leaves (value 8), dead seedlings (value 9). Plants with leaf chlorosis showing SES values between 1 and 3 were considered as a tolerant genotype, 4 to 6 as intermediate, and 7 to 9 as a susceptible genotype. For this evaluation the chlorosis of two last totally expanded leaves from three plants per pot were averaged and were consider as one measurement.

\section{Chlorophyll FLUORESCENCE}

Seven days after cold treatment, plants were acclimated to the dark at $25{ }^{\circ} \mathrm{C}$ for $30 \mathrm{~min}$ in a growth chamber and fluorescence was measured using the Dionisio-Sese \& Tobita (2000) protocol with a portable fluorometer (Hansatech, FMS 2). Fv/Fm, minimal fluorescence (F0) was determined by applying a weak modulated light $\left(0.4 \mu \mathrm{mol}\right.$ photons $\mathrm{m}^{-2}$ $\mathrm{s}^{-1}$ ) for $2 \mathrm{~s}$ and maximum fluorescence (FM) was induced by a short $0.8 \mathrm{~s}$ saturating light pulse $\left(9000 \mu \mathrm{mol}\right.$ photons $\mathrm{m}^{-2}$ $\mathrm{s}^{-1}$ ). The mean of measurements of chlorophyll fluorescence of three leaves of different plants per pot were considered as one replicate.

\section{Chlorophyll CONTENT}

This evaluation was performed using the extraction protocol defined by Zhang et al. (2009) with some modifications. Leaf samples of each genotype and their replicate were sampled 7 days after cold treatment. Subsequently, leaves were cut in small rectangles, placed on a mortar, ground to a fine powder in liquid nitrogen, transfered in a microtube of $1.6 \mathrm{ml}$, and weighed. Then, $600 \mu \mathrm{l}$ of acetone at $80 \% \mathrm{v} / \mathrm{v}$ and sodium carbonate $\left(\mathrm{Na}_{2} \mathrm{CO}_{3}\right)$ at $2 \% \mathrm{v} / \mathrm{v}$ were added. This mixture was stirred in a vortex (VM-300). When this process was completed, tubes were stored in a chamber at room temperature overnight. Samples were centrifuged on the next day at $16000 \mathrm{~g}$ for $10 \mathrm{~min}$ and the supernatant was removed to measure absorbance at $470 \mathrm{~nm}, 663 \mathrm{~nm}$, and $645 \mathrm{~nm}$ in a spectrophotometer (NanoDrop 2000). Total chlorophyll (Chl) content was determined with the equation described by Arnon (1949):

$\mathrm{Chl}=\left(20.31 \mathrm{~A}_{645}+8.05 \mathrm{~A}_{663}\right) / \mathrm{FW}\left[\mu \mathrm{g} \mathrm{g}^{-1}\right]$

$\mathrm{FW}=$ fresh weight tissue in grams.

\section{LIPID PEROXIDATION}

The protocol described by Dionisio-Sese \& Tobita (1998), with modifications, was used to determine lipid peroxidation. For this, the same leaves used for evaluation of chlorophyll content were used. A volume of $500 \mu \mathrm{l}$ of $50 \mathrm{mM}$ potassium phosphate buffer at $\mathrm{pH} 7$ was added to the sample that was stirred in a
Vortex and homogenized with a homogenizer (Heidolph, Diax 900). The extract was then centrifuged at $16000 \mathrm{~g}$ for $30 \mathrm{~min}$ at $4{ }^{\circ} \mathrm{C}$ (Eppendorf centrifuge 5415R). This process resulted in a $300 \mu \mathrm{l}$ aliquot of extract that was mixed with $300 \mu \mathrm{l} 0.5 \%$ thiobarbituric acid (TBA) in $20 \%$ trichloroacetic acid (TCA). Subsequently, the mixture was heated at $95{ }^{\circ} \mathrm{C}$ for $30 \mathrm{~min}$ (Thermoline, Cimarec 3) and when the reaction stopped, it was placed on ice for a few seconds and centrifuged at 10000 $\mathrm{g}$ for $10 \mathrm{~min}$ (Eppendorf centrifuge 5415R). Absorbance of 532 and $600 \mathrm{~nm}$ was determined in the supernatant with spectrophotometer (NanoDrop 2000). The MDA concentration was determined by the extinction coefficient, which is equal to $155 * 106 \mathrm{nmol}^{-1} \mathrm{~cm}^{-1}$ using the standard equation for weight in grams for each of the samples: $\mathrm{MDA}=\left[\left(\mathrm{A}_{532}-\mathrm{A}_{600}\right) / 155 *\right.$ $106 \mathrm{nmol}^{-1} \mathrm{~cm}^{-1}$ ] [nmol g-1 FW], where FW corresponding to fresh weight tissue in grams.

\section{Statistical AnALYSis}

Data normality and homoscedasticity were examined prior to calculate BLUPs values. When data was deviated from normality, was applied natural logarithm and exponential transformation. Data were analyzed statistically with an analysis of variance under a mixed model with random genotype effect and fixed block effects. The genetic merit of each genotype was evaluated by BLUP using restricted maximum likelihood (REML) for variance component estimation (Searle et al. 1992). Spearman correlation coefficient was calculated to determine relationships between the traits. Entry-mean broad-sense heritability for all traits was calculated using equation described by Doligez et al. (2013): $h^{2}=\sigma_{G}^{2} /\left(\sigma_{G}^{2}+\left(\sigma_{B}^{2} / n\right)\right)$

$\mathrm{h}^{2}=$ broad sense heritability.

$\sigma_{\mathrm{G}}^{2}=$ genotypic variance.

$\sigma^{2}{ }_{B}=$ block variance.

$\mathrm{n}=$ number of replicates $(\mathrm{n}=1$, when block effect was significant).

Finally, genotypes were clustered with an analysis of multivariate similarity based on Euclidean distance and Ward's method (Balzarini et al. 2008). All analyses were performed with the InfoStat statistical program and its interface with the lme4 package in R software (Di Rienzo et al. 2012).

\section{RESULTS}

Microclimatic CHARACTERIZATION

Rainfall was low in the period of experiment $(13 \mathrm{~mm})$ (Fig. 1). Mean of minimum air temperature ranged between 5 to 16 ${ }^{\circ} \mathrm{C}$, and mean of maximum air temperature ranged between 20 to $35^{\circ} \mathrm{C}$.

\section{LEAF CHLOROSIS}

Leaf chlorosis evaluation, based on SES scale, showed that $86.5 \%$ of the genotypes were cold tolerant, $10.8 \%$ 
intermediate, and $2.7 \%$ cold susceptible. The cold treatment resulted in mortality of susceptible control and very low damage in tolerant control (Fig. 2). The susceptible genotype control Oryzica 1 showed high leaf chlorosis and browning (scale value over 7.7) (Supplemental file 1). On the other hand, Ambar-INIA (cold tolerant genotype) showed low leaf chlorosis (scale value of 2.3). The most susceptible experimental lines were Quila 260312 and Quila 241607 with scale values of 7.3 and 7.0, respectively, and the best tolerant experimental lines were Quila 241304, Quila 241701, and Quila 256601, all of which had scale values of 1.7.

\section{Chlorophyll Fluorescence}

The analyzed genotypes showed Fv/Fm values between 0.40 and 0.86 (Supplemental file 1). In our study, $87.3 \%$ of genotypes showed Fv/Fm values higher than 0.80 . The susceptible genotype control Oryzica 1 showed a low Fv/ Fm ratio (0.40). Tolerant genotype control (Ambar-INIA) had high ratio of 0.83 . A subset of tolerant experimental lines consisted of Quila 223202, Quila 242002, Quila 241612, Quila 256101 and 242013, all of which had an Fv/Fm over 0.8, while the most susceptible experimental lines were Quila 64117 (0.66) and Quila 260312 (0.75). Genotypes with an Fv/Fm ratio lower than 0.80 exhibited greater damage in PSII.

\section{Chlorophyll CONTENT}

The genotype with the highest chlorophyll content had more than four times the pigment content than the Oryzica 1 with the lowest content (Supplemental file 1), while Ambar-INIA presented near to three times more $\mathrm{Chl}$ than susceptible control. Experimental lines with low Chl levels were Quila 64117, Quila 260312 and Quila 256001. Experimental lines with high levels of this pigment were Quila 242002, 241304 and 241305 .

\section{LIPID PEROXIDATION}

The genotypes evaluated in this study showed MDA concentrations between 1.40 and 8.17 nmol g-1 $\mathrm{FW}$ (Supplemental file 1). The susceptible genotype control Oryzica 1 had high MDA content $\left(8.17 \mathrm{nmol} \mathrm{g}^{-1}\right)$, while the tolerant genotype controls Ambar-INIA have low MDA content $\left(1.61 \mathrm{nmol} \mathrm{g}^{-1}\right)$. Experimental lines with high MDA levels were Quila 242007, Quila 64117, and Quila 241607 whereas the experimental lines with relatively low MDA levels were Quila 254701, Quila 244013, and Quila 242101.

\section{BROAD SENSE HERITABILITY}

Variance component and broad sense heritability for each trait were estimated. A low broad sense heritability value was found for Fv/Fm (0.1), while medium broad sense heritability values

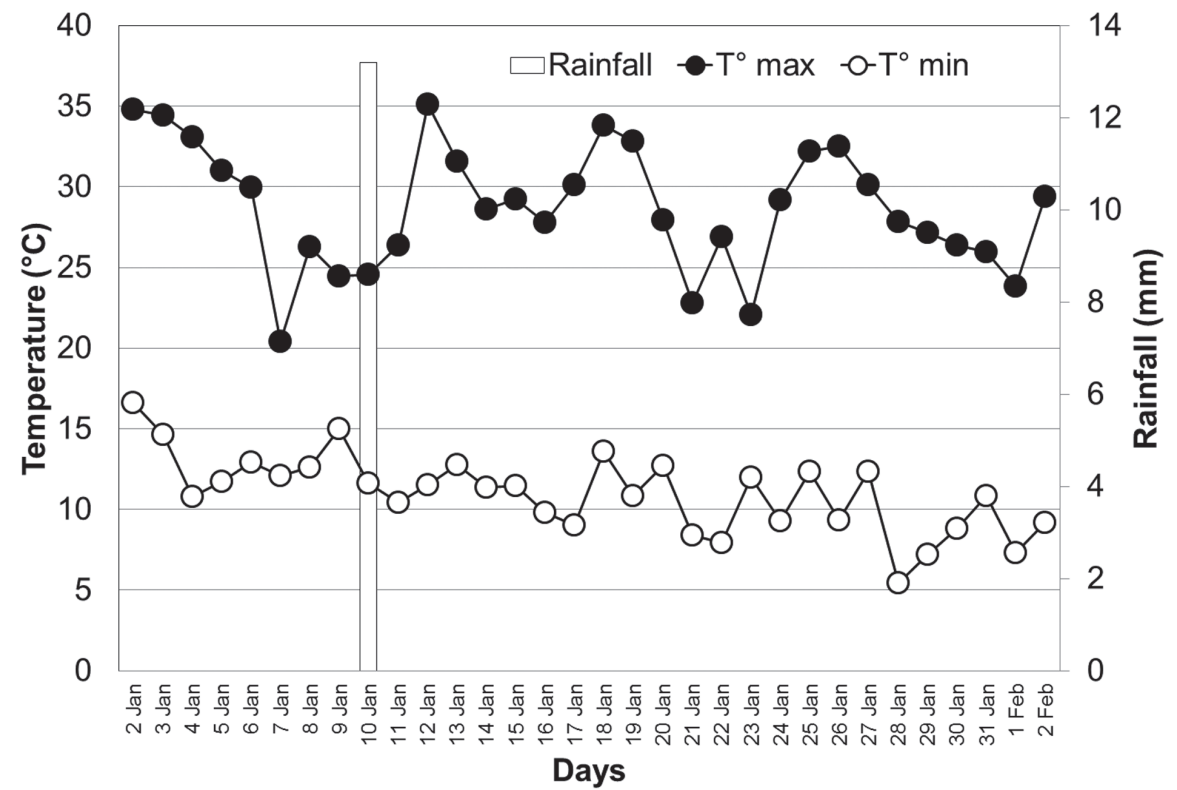

FiguRE 1. Rainfall and temperature when seedling where exposed to field conditions from January 1 st to February 2 nd 2014 . $T^{\circ}$ max: mean of daily maximum temperature; $\mathrm{T}^{\circ} \mathrm{min}$ : mean of daily minimum temperature.

Figura 1. Precipitaciones y temperaturas cuando las plántulas fueron expuestas a condiciones de campo desde el 1 de enero hasta el 2 de febrero de 2014. $\mathrm{T}^{\circ}$ max: media de las temperaturas máximas diarias; $\mathrm{T}^{\circ} \mathrm{min}$ : medias de las temperaturas mínimas diarias. 
were obtained for leaf MDA (0.20) and Chl content (0.22) (Table I). On the other hand, moderate broad sense heritability for leaf chlorosis, measured through SES (0.54) was observed.

MiXed MODEL AND MULTIVARIATE ANALYSIS

The distribution of BLUPs for SES, Fv/Fm and MDA in the genotypes was skewed toward cold tolerance values for each trait (Fig. 3). On the other hand Chl values for genotypes studied were normally distributed. High and low negative correlation was observed between SES and $\mathrm{Chl}$, and $\mathrm{Fv} / \mathrm{Fm}$ and SES, respectively. Low positive correlation was found between $\mathrm{Chl}$ and MDA, and no correlation was observed between Fv/Fm and MDA, and Fv/Fm and Chl (Table II). Results of principal components of Linear Unbiased Prediction (BLUP) of genotype effects for several cold tolerance traits are shown in Tables III and IV. The first two principal components explain $75 \%$ of the total variance (Table III) and the first component contributed $55 \%$ of the total variance. The correlations of this axis with the original cold tolerance variables indicate that $\mathrm{Chl}$ and $\mathrm{Fv} / \mathrm{Fm}$ were the variables with the most negative contribution, while with the most positive contribution was SES evaluation (Table IV). In the second component, lipid peroxidation had a positive contribution, while Chl had a negative contribution. The opposite projection of SES to $\mathrm{Chl}$ and $\mathrm{Fv} / \mathrm{Fm}$ means that plants with low levels of leaf chlorosis and lipid peroxidation had high levels of $\mathrm{Chl}$ and Fv/Fm (Fig. 4). The biplot analysis shows a positive correlation between $\mathrm{Chl}$ and $\mathrm{Fv} /$ Fm. Quila 260312, 241607, Quila 64117, and Oryzica 1 were the genotypes with the most positive projection on the first principal component and were located distant from other genotypes. These genotypes were more susceptible to low temperatures. Conversely, Quila 242002 and Quila 241304 were considering as the highest cold-tolerant genotype because were observed opposite to SES and near to $\mathrm{Chl}$ content in the biplot. Four differentiated groups of genotypes were described from the cluster analysis (Fig. 5, Table V). The first group (I), included the most susceptible genotypes, Oryzica 1 (cold-susceptible control) and three experimental lines. The second group (II), included intermediate tolerant genotypes that are 43 experimental lines. The third group (III), included low tolerant genotypes, with 20 experimental lines. Finally, the third group (IV), was classified as tolerant and included Ambar-INIA and 43 experimental lines.

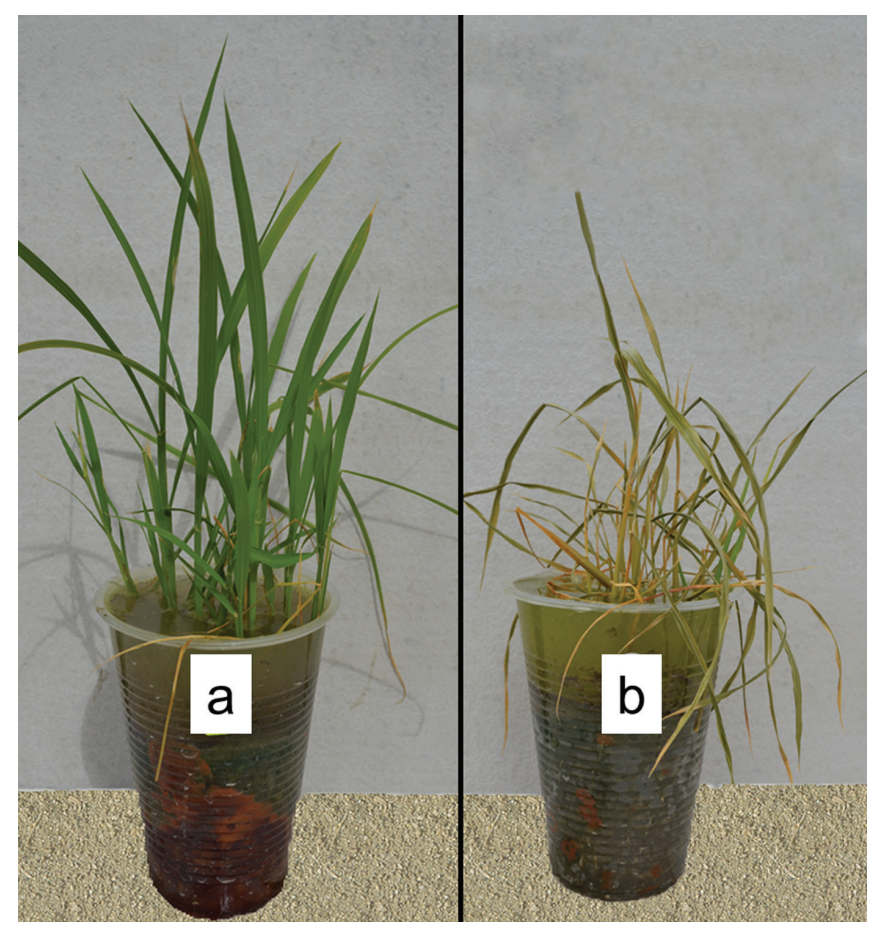

FiguRE 2. Check cultivars for cold tolerance seven days after cold stress. a: Ambar-INIA, was used as check-tolerance. b: Oryzica 1, was used as check-susceptible. In visual rating, cold tolerant cultivar showed a low damage with low levels of leaf chlorosis and browning. In contrast, susceptible check, Oryzica 1, presented a high damage including leaf chlorosis, browning and necrosis.

Figura 2. Cultivares testigos de tolerancia al frío siete días después del estrés por frío. a; Ambar-INIA, fue utilizado como testigo tolerante. b: Oryzica 1, fue utilizado como testigo susceptible. En el análisis visual, el cultivar tolerante mostró poco daño con bajos niveles de clorosis foliar y pardeamiento. En contraste, el testigo susceptible presentó altos niveles de daño, incluyendo clorosis foliar, pandeamiento y necrosis. 
Gayana Bot. 72(1), 2015

TABLE I. Variance component and broad sense heritability estimation.

TABLA I. Componentes de la varianza y estimación de la heredabilidad en sentido amplio.

\begin{tabular}{lllll} 
TRAIT & $\sigma_{\mathrm{P}}^{2}$ & $\sigma_{\mathrm{G}}^{2}$ & $\sigma_{\mathrm{B}}^{2}$ & $\mathrm{~h}^{2}$ \\
\hline SES & 0.0505 & 0.0144 & 0.0361 & 0.54 \\
$\mathrm{FV} / \mathrm{Fm}$ & 0.0010 & 0.0001 & 0.0009 & 0.10 \\
Chl & 3482.4 & 762.8 & 2719.6 & 0.22 \\
MDA & 0.0212 & 0.0016 & 0.0196 & 0.20
\end{tabular}

$\mathrm{h}^{2}=$ Broad sense heritability; $\sigma_{\mathrm{P}}^{2}=$ phenotypic variance; $\sigma_{\mathrm{G}}^{2}=$ genotypic variance; $\sigma_{\mathrm{B}}^{2}=$ Block variance. $/ \mathrm{h}^{2}=$ Heredabilidad en sentido amplio; $\sigma_{\mathrm{P}}^{2}=$ varianza fenotípica; $\sigma_{\mathrm{G}}^{2}=$ varianza genotípica; $\sigma_{\mathrm{B}}^{2}=$ varianza del bloque.

TABLE II. Correlation coefficients between traits evaluated: standard evaluation system scale (SES), maximum quantum yield of Photosystem II (Fv/Fm), Chlorophyll content (Chl), Malondialdehyde concentration (MDA).

TABLA II. Coeficientes de correlación entre los atributos evaluados: escala del sistema de evaluación estándar (SES), eficiencia máxima fotoquímica del fotosistema II (Fv/Fm), contenido de clorofila (Chl), concentración de malondialdehido (MDA).

\begin{tabular}{lcccc} 
Trait & Fv/FM & MdA & Ses & ChL \\
\hline Fv/Fm & \multirow{2}{*}{1.00} & 0.02 & $-0.21 *$ & 0.03 \\
MDA & & 1.00 & $0.25 *$ & $0.18^{*}$ \\
SES & & & 1.00 & $-0.41 *$ \\
Chl & & & & 1.00
\end{tabular}

* Significant at the 0.001 probability level.

TABLE III. Principal component analysis of genetic merits for four variables used to evaluate cold tolerance in rice genotypes.

TABLA III. Análisis de componentes principales de los méritos genéticos para las cuatro variables usadas para evaluar la tolerancia al frío en los genotipos de arroz.

\begin{tabular}{ccc} 
PRINCIPAL COMPONENTS & PROPORTION & CUMULATIVE PROPORTION \\
\hline 1 & 0.55 & 0.55 \\
2 & 0.20 & 0.75 \\
3 & 0.16 & 0.91 \\
4 & 0.09 & 1.00
\end{tabular}

TABLE IV. Weighted coefficients of variance explained for each variable used for principal components 1 and 2.

TABLA IV. Contribución de los coeficientes de varianza explicados para cada variable usada en los componentes principales 1 y 2.

\begin{tabular}{lrr} 
VARIABLES & PC1 & PC2 \\
\hline BLUP SES & 0.58 & 0.10 \\
BLUP FV/Fm & -0.48 & -0.08 \\
BLUP Chl & -0.52 & -0.49 \\
BLUP MDA & -0.41 & 0.86
\end{tabular}

Principal component 1 (PC1); principal component 2 (PC2); best linear unbiased prediction (BLUP); standard evaluation system scale (SES); maximum quantum yield of Photosystem II (Fv/Fm); chlorophyll content (Chl); malondialdehyde concentration (MDA). / Componente principal 1 (PC1); componente principal 2 (PC2); mejor predictor lineal insesgado (BLUP); escala del sistema de evaluación estándar (SES); eficiencia máxima fotoquímica del fotosistema II (Fv/Fm); contenido de clorofila (Chl); concentración de malondialdehido (MDA). 
Cold tolerance evaluation in temperate rice seedling: DonOso, G. ET AL.
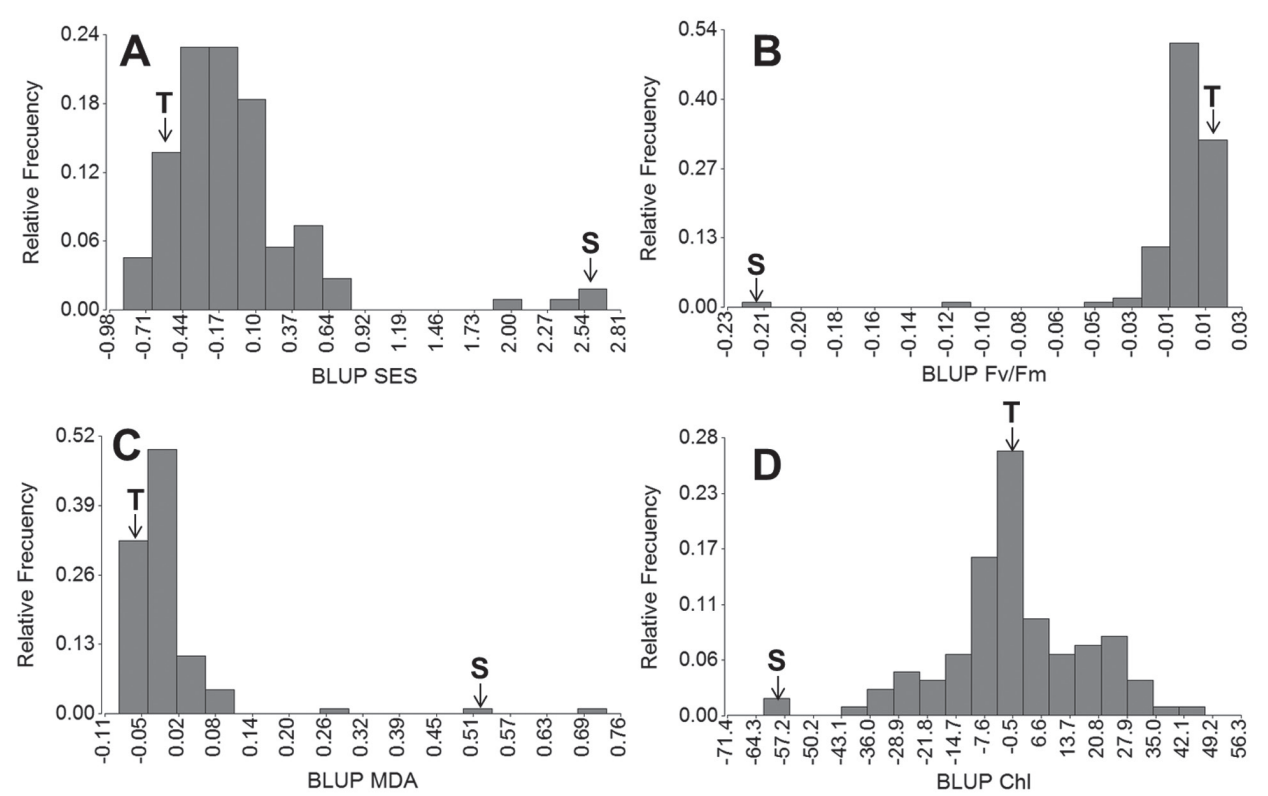

FigURE 3. Distribution of BLUPs for different traits evaluated. A; BLUPs for standard evaluation system scale (SES). B; BLUPs for maximum quantum yield of Photosystem II (Fv/Fm). C; BLUPs for Malondialdehyde concentration (MDA). D; BLUPs for Chlorophyll content (Chl). T: tolerant genotype, Ambar-INIA; S: susceptible genotype, Oryzica 1.

Figura 3. Distribución de los BLUPs para los diferentes parámetros evaluados A; BLUPs para la escala del sistema de evaluación estándar (SES). B; BLUPs para la eficiencia máxima fotoquímica del fotosistema II (Fv/Fm). C; BLUPs para la concentración de malondialdehido (MDA). D; BLUPs para el contenido de clorofila (Chl). T: genotipo tolerante, Ambar-INIA; S: genotipo susceptible, Oryzica 1.

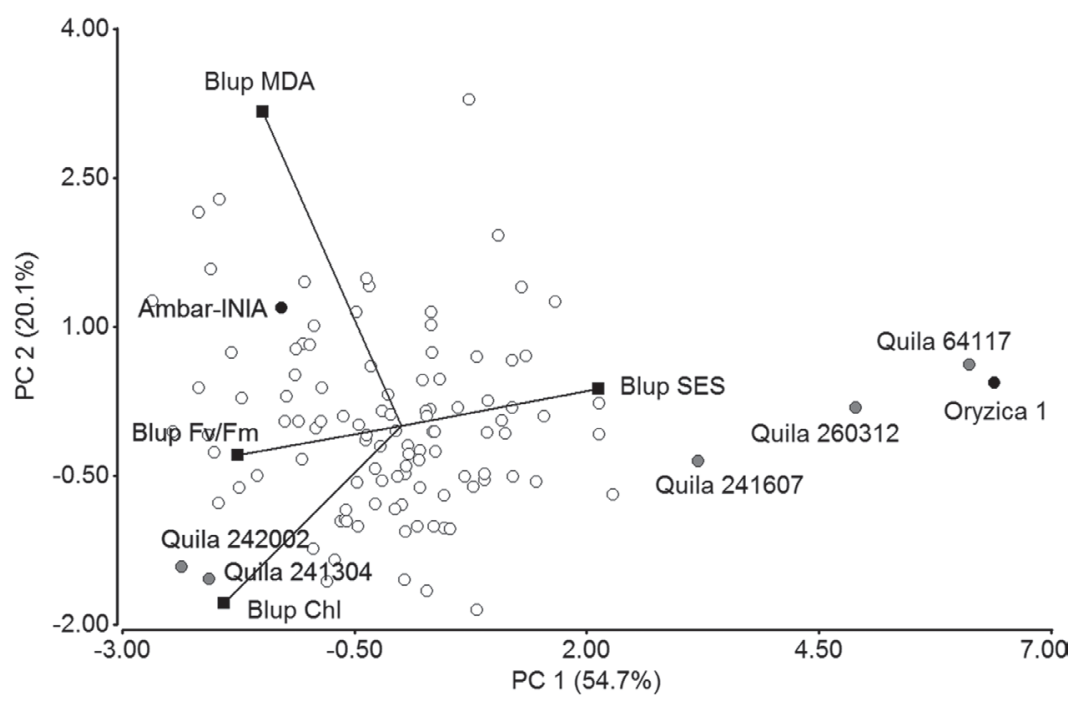

Figure 4. Biplot based on BLUPs of 4 traits studied in all genotypes. Axes X and Y show principal components 1 and 2, respectively. Lines show BLUP for each trait studied. Best linear unbiased prediction (BLUP); standard evaluation system scale (SES); maximum quantum yield of Photosystem II (Fv/Fm); chlorophyll content (Chl); malondialdehyde concentration (MDA). The circle represents the rice genotypes.

Figura 4. Biplot basado en los BLUPS de los 4 atributos estudiados en todos los genotipos. Los ejes X e Y muestran los componentes principales 1 y 2, respectivamente. Las líneas representan los BLUP para cada atributo estudiado. Mejor predictor lineal insesgado (BLUP); escala del sistema de evaluación estándar (SES); eficiencia máxima fotoquímica del fotosistema II (Fv/Fm); contenido de clorofila (Chl); concentración de malondialdehido (MDA). Los círculos representan los genotipos de arroz estudiados. 
Gayana Bot. 72(1), 2015

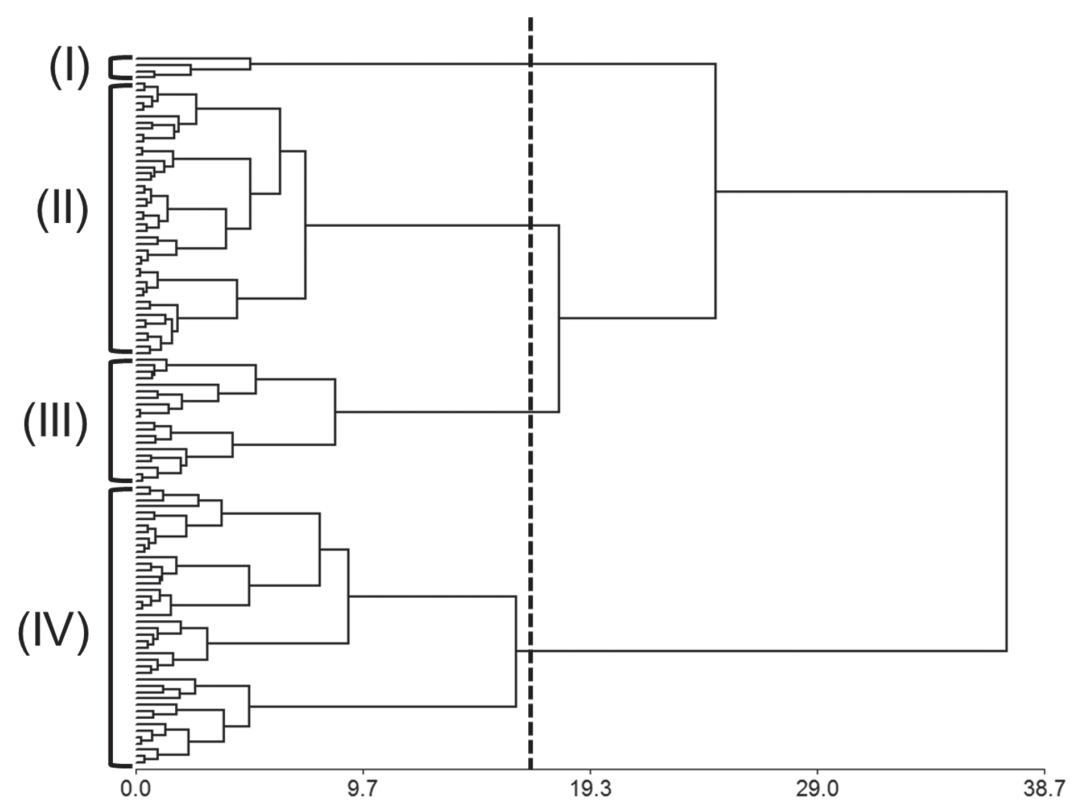

FigURE 5. Dendrogram of cluster analysis based on BLUP of traits studied. Analysis of similarity was based on Ward's method using Euclidean distance. Dashed line show the reference point used to analyze the clustering. Four clusters were identifying (I, II, III and IV).

Figura 5. Dendrograma del análisis de conglomerado basado en los BLUPs de los atributos estudiados. El análisis de similitud fue basado en el método de Ward utilizando la distancia Euclídea. La línea discontinua muestra el punto de referencia utilizado para analizar el conglomerado. Cuatro conglomerados fueron identificados (I, II, III and IV).

TABLE V. Classification of 111 rice genotypes according to their cold-tolerance based in cluster analysis.

TABLA V. Clasificación de los 111 genotipos de arroz estudiados según su tolerancia al frío basado en el análisis de conglomerado.
Group Cold-TOLerance
GENOTYPES

I Susceptible

II Intermediate tolerant

Oryzica 1, Quila 241607, Quila 260312 and Quila 64117.

INIAG 144, INIAG 172, INIAG 70, INIAG 79, INIAG 99, Quila 216202, Quila 216501, Quila 222204, Quila 231701, Quila 240101, Quila 240103, Quila 241610, Quila 241703, Quila 242007, Quila 242108, Quila 242112, Quila 242121, Quila 242203, Quila 242609, Quila 242610, Quila 242612, Quila 242616, Quila 242701, Quila 242703, Quila 242802, Quila 242808, Quila 243008, Quila 249002, Quila 249006, Quila 249301, Quila 249304, Quila 252201, Quila 252702, Quila 253701, Quila 254101, Quila 256103, Quila 256501, Quila 256602, Quila 256603, Quila 260404, RQuila 17, RQuila 356 and RQuila 363.

III Low tolerant INIAG 257, INIAG 115, INIAG 165, INIAG 169, Quila 194602, Quila 194603, Quila 200112, Quila 208902, Quila 241307, Quila 241801, Quila 242012, Quila 242106, Quila 242204, Quila 242608, Quila 242613, Quila 249104, Quila 252801, Quila 254701, Quila 256001 and Quila 256901.

IV Tolerant Ambar-INIA, INIAG 27, Quila 241313, Quila 213007, Quila 222703, Quila 223105, Quila 223202, Quila 224802, Quila 225102, Quila 240208, Quila 241304, Quila 241305, Quila 241315, Quila 241319, Quila 241321, Quila 241605, Quila 241612, Quila 241701, Quila 242002, Quila 242003, Quila 242006, Quila 242010, Quila 242011, Quila 242101, Quila 242114, Quila 242115, Quila 242207, Quila 242415, Quila 242420, Quila 242504, Quila 243010, Quila 244013, Quila 249101, Quila 249103, Quila 249203, Quila 249303, Quila 251303, Quila 253003, Quila 256002, Quila 256101, Quila 256104, Quila 256106, Quila 256601 and Quila 256701. 


\section{DISCUSSION}

The cold tolerance evaluation using SES scale, allowed us to find genotypes with high cold tolerance at seedling stage. In a similar study, treatment of $4{ }^{\circ} \mathrm{C}$ by three days was enough to predict survival ratio of genotypes at seedling stage (Koseki et al. 2010). In contrast, widely applied evaluations at $9{ }^{\circ} \mathrm{C}$ and $10{ }^{\circ} \mathrm{C}$, need between 10 to 14 days of stress treatment to properly asses cold tolerance in rice (Da Cruz et al. 2010, Ji et al. 2010, Kim \& Tai 2011, Kim et al. 2012).

Chlorophyll fluorescence analysis is considered one of the best indicators to measure photoinhibition of photosystem II (PSII) (Bonnecarrère et al. 2011). Photochemical efficiency of PSII is essential to determine cold tolerance in rice plants since it is directly related to photoinhibition caused by low temperatures at vegetative stage of the crop (Jeong et al. 2002). However, poor differentiation between genotypes was observed using chlorophyll fluorescence evaluation, because the high percentage of genotypes presented healthy values, over 0.8 . Krause and Weis (1991) determined that standard value of 0.8 in the $\mathrm{Fv} / \mathrm{Fm}$ ratio indicates acceptable rate of photosynthesis and thus low photoinhibition. Only the three most susceptible genotypes presented low values. Similar results were reported by Bonnecarrère et al. (2011), who show a decrease in the Fv/ Fm values in rice cultivars after low temperature treatment.

The evaluation of chlorophyll content after cold treatment showed a good discrimination of cold tolerance between the genotypes. This trait allowed find genotypes with tolerance greater than control tolerant, Ambar-INIA. Low Chl after low temperature treatments was observed by Dai et al. (1990), who reported that chlorophyll decreased approximately $80 \%$ in rice leaves. High $\mathrm{Chl}$ in experimental lines could be due to the protection mechanism's better response against damage caused by low temperatures through carotenoids, such as $\beta$-carotene and xanthophylls (Tambussi 2004, Huang \& Guo 2005), which reduce or prevent oxidative stress and its damaging effects by dissipating excess energy such as heat (Trebst 2003).

The measurement of lipid peroxidation through evaluation of MDA concentration is considered as biochemical marker of lipid membrane injury by cold (Verma \& Dubey 2003). A high MDA concentration indicates oxidative damage (Yun et al. 2010). Low MDA concentration in tolerant control genotype and high levels in susceptible control genotype was observed. High levels of MDA concentration were observed after cold stress in rice. This agrees with the results reported by Kim \& Tai (2011), who also found differences in MDA concentration in seedling rice after being subjected to cold conditions of $9{ }^{\circ} \mathrm{C}$ for $14 \mathrm{~d}$. Low MDA levels in experimental lines are possibly due to the increased presence of enzymatic and non-enzymatic antioxidants, which play important role in the survival of seedlings during a period of stress (Foyer et al. 1997, Malecka et al. 2001, Kim \& Tai 2011). Cold stress in rice can cause increase in the activity of superoxide dismutase
(SOD) (Kuk et al. 2003), ascorbate peroxidase (APX), and glutathione reductase (GR) (Moradi \& Ismail 2007). In addition, non-enzymatic systems allow detoxification through the xanthophyll cycle in rice seedlings after cold exposure (Bonnecarrère et al. 2011). However poor differentiation was observed between experimental lines using this trait.

Low heritability was calculated for Fv/Fm values which can be an indicator of high environmental influence in this trait. SES was confirmed as the good parameter for selecting cold-tolerant rice genotypes due to good values of heritability. On the other hand, Chl content could be used in future analysis because of significant positive correlation with SES (0.41) and normal distribution of the data. However, moderate broad sense heritability calculated for this trait $(0.22)$ required the use of SES scale in all evaluations, as control.

The combination of BLUP and multivariate analysis of all traits, allowed to differentiate between genotypes with low cold tolerance and genotypes with intermediate cold tolerance. Related works have used this methodology successfully for genotype selection (Balestre et al. 2010, Thomason \& Phillips 2006). Using this methodology we selected two candidate genotypes with promising cold tolerance. Finally, our findings could be applied in the temperate rice production areas, they are likely to be of great interest to the international groups working on this subject.

\section{CONCLUSIONS}

The multivariate analysis of morphophysiological traits allowed the hierarchical ordering of rice genotypes at the seedling stage of Rice Breeding Program according to cold damage. Analysis of lipid peroxidation in the different genotypes was not related to visual cold damage. Furthermore, Chl was successfully related to visual cold damage. Cold tolerance of $39 \%$ of the experimental lines evaluated can be explained by the systematic use of high cold tolerance Chilean varieties in the crosses. The experimental lines with high cold tolerance have high importance to increase cold tolerance at seedling stage in the Rice Breeding Program. Genotypes with highest tolerance to cold were Quila 242002 and Quila 241304, while genotypes more susceptible at low temperatures were Quila 64117, Quila 260312 and 241607. Based on this results, we suggest that SES and Chl content were the most suitable traits to evaluate cold tolerance in rice seedlings at these conditions. These traits allow increase the accuracy in cold tolerance evaluation of the experimental lines studied.

\section{ACKNOWLEDGEMENTS}

The authors would like to thank to Chilean Science and Technology Fund FONDECYT (Grant N.1110405) and FONDEF (grant $\mathrm{N}^{\circ} \mathrm{D} 10 \mathrm{I1183}$ ) for supporting this research. 


\section{REFERENCES}

Aghaee, A., F. Moradi, H. Zare-Maivan, F. Zarinkamar, H. Pour Irandoost \& P. Sharifi. 2011. Physiological responses of two rice (Oryza sativa L.) genotypes to chilling stress at seedling stage. African Journal of Biotechnology 10: 76177621.

Allen, D.J. \& D.R. ORT. 2001. Impacts of chilling temperatures on photosynthesis in warm-climate plants. Trends in Plant Science 6: 36-42.

Alvarado, J.R. \& P. Grau. 1991. Mejoramiento del arroz en Chile por tolerancia a frío. En: J.P. Puignau (ed.), Reunión sobre mejoramiento de arroz en el Cono Sur. 17-21 de julio, 1989. IICA. PROCISUR. Montevideo, Uruguay.

Alvarado, R. \& S. Hernaiz. 2007. Antecedentes generales sobre el arroz en Chile. En: R. Alvarado (ed.), Arroz. Manejo tecnológico. Boletín INIA $\mathrm{N}^{\circ}$ 162. 179 pp. Instituto de Investigaciones Agropecuarias INIA, Centro Regional de Investigación Quilamapu, Chillán, Chile.

AndaYA, V.C. \& D.J. Mackill. 2003. Mapping of QTLs associated with cold tolerance during the vegetative stage in rice. Journal of Experimental Botany 54: 2579-2585.

AndaYa, V.C. \& T.H. TAI. 2006. Fine mapping of the qCTS12 locus, a major QTL for seedling cold tolerance in rice. Theoretical and Applied Genetics 113: 467-475.

ARNon, D.I. 1949. Copper enzymes in isolated chloroplasts polyphenol oxidase in Beta vulgaris. Plant Physiology 24: 1-15.

Balestre, M., V.B. Santos, A.A. Soares \& M.S. Reis. 2010. Stability and adaptability of upland rice genotypes. Crop Breeding and Applied Biotechnology 10: 357-363.

Balzarini, M.G., L. González, M. Tablada, F. Casanoves, J.A. Di Rienzo \& C.W. Robledo. 2008. Manual del Usuario, Editorial Brujas, Córdoba, Argentina. 336 pp.

Bonnecarrère, V., O. Borsani, P. Díaz, F. Capdevielle, P. Blanco \& J. MonZA. 2011. Response to photoxidative stress induced by cold in japonica rice is genotype dependent. Plant Science 180: 726-732.

Bosetti F., C. Montebelli, A.D. Novembre, H.P. Chamma \& J.B. PINHEIRO. 2012. Genetic variation of germination cold tolerance in Japanese rice germplasm. Breeding Science 62: 209-215.

Campos, P.S., V. Quartin, J.C. Ramalho \& M.A. Nunes. 2003. Electrolyte leakage and lipid degradation account for cold sensitivity in leaves of Coffea sp. plants. Journal of Plant Physiology 160: 283-292.

Da Cruz, R., S.C. Milach \& L.C. Federizzi. 2006. Inheritance of rice cold tolerance at the germination stage. Genetics and Molecular Biology 29: 314-320.

Da Cruz R.P., I.T.L. Duarte \& C. Cabreira. 2010. Inheritance of rice cold tolerance at the seedling stage. Scientia Agricola 67: 669-674.

Da Cruz R.P., R.A. Sperotto, D. Cargnelutti, J.M. Adamski, T. De Freitasterra \& J.P. Fett. 2013. Avoiding damage and achieving cold tolerance in rice plants. Food and Energy Security 2: 96-119.

DaI, Q., B.S. Vergara \& R.M. Visperas. 1990. Amelioration of cold injury in rice (Oryza sativa L.): improving root oxidizing activity by plant growth regulators. Philippine Journal of Crop Science 15: 49-54.

De los Reyes, B.G., M. Morsy, J. Gibbons, T.S.N. Varma, W.
Antoine, J.M. Mcgrath, R. Halgren \& M. Redus. 2003. A snapshot of the low temperature stress transcriptome of developing rice seedling (Oryza sativa L.) via ESTs from subtracted cDNA library. Theoretical and Applied Genetics 107: 1071-1082.

Díaz, S., R. Morejón, R. Castro \& N. Pérez. 2006. Comportamiento de genotipos de arroz (Oryza sativa L.) seleccionados para tolerancia a bajas temperaturas en siembra temprana de frío. Cultivos Tropicales 27: 71-75.

Dionisio-Sese, M.L. \& S. Tobita. 1998. Antioxidant responses of rice seedlings to salinity stress. Plant Science 135: 1-9.

Dionisio-Sese, M.L. \& S. ToBita. 2000. Effects of salinity on sodium content and photosynthetic responses of rice seedlings differing in salt tolerance. Journal of Plant Physiology 157: 54-58.

Di Rienzo, J.A., F, Casanoves, M.G. Balzarini, L. González, M. Tablada \& C.W. Robledo. Infostat Versión (2012) Grupo InfoStat, FCA, Universidad Nacional de Córdoba, Argentina. URL http://www.infostat.com.ar.

Doligez A, Y. Bertrand, M. Farnos, M. Grolier, C. Romieu, F. Esnault, S. Dias, G. Berger, P. François, T. Pons, P. Ortigosa, C. Roux, C. Houel, V. Laucou, R. Bacilieri, J.-P. PÉros \& P. This. 2013. New stable QTLs for berry weight do not colocalize with QTLs for seed traits in cultivated grapevine (Vitis vinifera L.). BMC Plant Biology 13: $217-$ 232.

Foyer, C.H., H. López-Delgado, J.F. Dat \& I.M. Scott. 1997. Hydrogen peroxide- and glutathione-associated mechanisms of acclimatory stress tolerance and signalling. Physiologia Plantarum 100: 241-254.

Fujino, K., H. Sekiguchi, T. Sato, H. Kiuchi, Y. Nonoue, Y. Takeuchi, T. ANDO, S.Y. Lin \& M. YANO. 2004. Mapping of quantitative trait loci controlling low-temperature germinability in rice (Oryza sativa L.). Theoretical and Applied Genetics 108: 794-799.

Heffner, E.L., M.E. Sorrells \& J.-L. Jannink. 2009. Genomic selection for crop improvement. Crop Science 49: 1-12.

Hill, R.R. JR. \& J.L. Rosenberger. 1985. Methods for combining data from germplasm evaluation trials. Crop Science 25: 467-470.

Howarth, C.J. \& H.J. Ougham. 1993. Gene expression under temperature stress. New Phytologist 125: 1-26.

Huang, M. \& Z. Guo. 2005. Responses of antioxidative system to chilling stress in two rice cultivars differing in sensitivity. Biologia Plantarum 49: 81-84.

IRRI. 2009. Rice standard evaluation system: cold tolerance (Ctol). Rice Knowledge Bank. http://www.knowledgebank.irri. $\mathrm{org} /$ extension/index.php/temperature/cold-tolerance-ctol. Accessed 19 Oct 2011.

Jeong, S.W., S.M. Choi, D.S. Lee, S.N. Ahn, Y. Hur, W.S. Chow \& Y.I. PARK. 2002. Differential susceptibility of photosynthesis to light-chilling stress in rice (Oryza sativa L.) depends on the capacity for photochemical dissipation of light. Molecules and cells 13: 419-428.

Ji, Z.Z., Y.X. ZenG, D.L. ZeNG, L.Y. MA, X.M. Li, B.X. LiU. \& C.D. YANG. 2010. QTL for rice cold tolerance identified at plumule and 3-leaf-seedling stage using QTL network software. Rice Science 17: 282-287.

KIM, S.-I. \& T.H. TAI. 2011. Evaluation of seedling cold tolerance in rice cultivars: a comparison of visual ratings and quantitative indicators of physiological changes. Euphytica 178: 431-447. 
KIM, S., D. Kiм \& T.H. TAI. 2012. Evaluation of rice seedling cold tolerance to constant and intermittent low temperature stress. Rice Science 19: 295-308.

Koseki, M., N. Kitazawa, S. Yonebayashi, Y. Maehara, Z.X. Wang \& Y. MinOBE. 2010. Identification and fine mapping of a major quantitative trait locus originating from wild rice, controlling cold tolerance at the seedling stage. Molecular Genetics and Genomics 284: 45-54.

Krause, G.H. \& E. Weis. 1991. Chlorophyll fluorescence and photosynthesis: The basics. Annual Review of Plant Physiology and Plant Molecular Biology 42: 313-349.

Kuk, Y.I., J.S. Shin, N.R. Burgos, T.E. Hwang, O. Han, B.H. Cho, S. Jung \& J.O. GuH. 2003. Antioxidative enzymes offer protection from chilling damage in rice plants. Crop Science 43: 2109-2117.

Malecka, A., W. Jarmuszkiewicz \& B. TomaszewsKa. 2001. Antioxidative defense to lead stress in subcellular compartments of pea root cells. Acta Biochimica Polonica 48: 678-698.

Moradi, F. \& A.M. Ismail. 2007. Responses of photosynthesis, chlorophyll fluorescence and ROS-scavenging systems to salt stress during seedling and reproductive stages in rice. Annals of Botany 99: 1161-1173.

PArK, I.K., C.S. OH, D.M. Kim, S.M. Yeo \& S.N. AhN. 2013. QTL mapping of cold tolerance at the seedling stage using introgression lines derived from an intersubspecific cross in rice. Plant Breeding \& Biotechnology 1: 1-8.

Piepho, H.P., J. Möhring, A.E. Melchinger \& A. Büchse. 2008. BLUP for phenotypic selection in plant breeding and variety testing. Euphytica 161: 209-228.

Sanghera G.S., S.H. Wani, W. Hussain \& N.B. Singh. 2011. Engineering cold stress tolerance in crop plants. Current genomics. 12: 30-43.

Searle, S.R., G. Casella \& C.E. Mcculloch. 1992. Variance components. New York: J. Wiley. 528 pp.

Sikuku, P.A., G.W. Netondo, J.C. Onyango \& D.M. Musyimi. 2010. Chlorophyll fluorescence, protein and chlorophyll content of three nerica rainfed rice varieties under varying irrigation regimes. Journal of Agricultural and Biological Science 5: 19-25.

SuZuKI, K., K. NAgasuga \& M. OKada. 2008. The chilling injury induced by high root temperature in the leaves of rice seedlings. Plant and Cell Physiology 49: 433-442.

TAmBussi, E.A. 2004. Fotosíntesis, fotoprotección, productividad, y estrés abiótico: algunos casos de estudio. Dissertation, Universitat de Barcelona. 231 pp.

Thomason, W.E. \& S.B. Phillips. 2006. Methods to evaluate wheat cultivar testing environments and improve cultivar selection protocols. Field Crops Research 99: 87-95.

Torres, E.A. \& I.O. Geraldi. 2007. Partial diallel analysis of agronomic characters in rice (Oryza sativa L.). Genetics and Molecular Biology 30: 605-613.

TREBST, A. 2003. Function of $\beta$-carotene and tocopherol in photosystem II. Zeitschrift für Naturforschung C 58: 609-620.

Verma, S. \& R. Dubey. 2003. Lead toxicity induces lipid peroxidation and alters the activities of antioxidant enzymes in growing rice plants. Plant Science 164: 645-655.

Ye, C., S. Fukai, I. Godwin, R. Reinke, P. Snell, J. Schiller \& J. BASNAYAKE. 2009. Cold tolerance in rice varieties at different growth stages. Crop \& Pasture Science 60: 328-338.

Yoshida, S. 1981. Fundamentals in rice crop science. International Rice Research Institute, Los Baños, Laguna, Philippines. $269 \mathrm{pp}$.

Yun, K.-Y., M.R. Park, B. Mohanty, V. Herath, F. Xu, R. Mauleon, E. Wijaya, V.B. Bajtc, R. Bruskiewich \& B.G. De Los Reyes. 2010. Transcriptional regulatory network triggered by oxidative signals configures the early response mechanisms of japonica rice to chilling stress. BMC Plant Biology 10: 16.

Zhang, J., C. HAN \& Z. Liu. 2009. Absorption spectrum estimating rice chlorophyll concentration: preliminary investigations. Journal of Plant Breeding and Crop Science 1: 223-229.

Zhang, J., J. LI, X. WANG \& J. Chen. 2011. OVP1, a vacuolar $\mathrm{H}+$-translocating inorganic pyrophosphatase (V-PPase) overexpression improved rice cold tolerance. Plant Physiology and Biochemistry 49: 33-38.

Supplemental data. Means of traits values evaluated in rice genotypes studied. Standard evaluation system scale (SES); maximum quantum yield of Photosystem II (Fv/Fm); chlorophyll content ( $\mathrm{Chl})$; malondialdehyde concentration (MDA). \pm SE corresponding to standard error of three repetitions.

Datos suplementarios. Medias de los valores para atributos evaluados en los genotipos de arroz estudiados. Escala del sistema de evaluación estándar (SES); eficiencia máxima fotoquímica del fotosistema II (Fv/Fm); contenido de clorofila (Chl); concentración de malondialdehido (MDA). \pm SE corresponde al error estándar de tres repeticiones.

\begin{tabular}{rlllll}
$\mathrm{N}^{\circ}$ & GENOTYPE & $\mathrm{SES} \pm \mathrm{SE}$ & $\mathrm{Fv} / \mathrm{Fm} \pm \mathrm{SE}$ & $\mathrm{Chl} \pm \mathrm{SE}$ & $\mathrm{MDA} \pm \mathrm{SE}$ \\
\hline 1 & Ambar & $2.33 \pm 0.67$ & $0.83 \pm 0.01$ & $187.3 \pm 29.6$ & $1.61 \pm 0.07$ \\
2 & INIAG 115 & $3.00 \pm 0.00$ & $0.81 \pm 0.02$ & $169.0 \pm 18.6$ & $1.78 \pm 0.13$ \\
3 & INIAG 144 & $3.00 \pm 0.00$ & $0.82 \pm 0.02$ & $175.1 \pm 11.9$ & $2.37 \pm 0.45$ \\
4 & INIAG 165 & $3.67 \pm 0.88$ & $0.82 \pm 0.02$ & $124.2 \pm 9.6$ & $2.16 \pm 0.32$ \\
5 & INIAG 169 & $3.67 \pm 0.67$ & $0.82 \pm 0.03$ & $108.3 \pm 27.0$ & $1.99 \pm 0.29$ \\
6 & INIAG 172 & $3.00 \pm 0.00$ & $0.83 \pm 0.02$ & $182.7 \pm 33.2$ & $2.60 \pm 0.16$ \\
7 & INIAG 257 & $3.33 \pm 0.33$ & $0.79 \pm 0.03$ & $182.8 \pm 27.2$ & $2.25 \pm 0.32$ \\
8 & INIAG 27 & $2.67 \pm 0.33$ & $0.83 \pm 0.03$ & $254.1 \pm 17.4$ & $1.87 \pm 0.06$ \\
9 & INIAG 70 & $4.00 \pm 1.00$ & $0.82 \pm 0.02$ & $155.6 \pm 48.0$ & $2.28 \pm 0.40$ \\
10 & INIAG 79 & $2.33 \pm 0.67$ & $0.82 \pm 0.02$ & $179.2 \pm 14.4$ & $2.24 \pm 0.20$ \\
11 & INIAG 99 & $3.33 \pm 0.33$ & $0.84 \pm 0.01$ & $151.2 \pm 33.2$ & $2.21 \pm 0.08$
\end{tabular}


Gayana Bot. 72(1), 2015

\begin{tabular}{|c|c|c|c|c|c|}
\hline $\mathrm{N}^{\circ}$ & GENOTYPE & $\mathrm{SES} \pm \mathrm{SE}$ & $\mathrm{Fv} / \mathrm{Fm} \pm \mathrm{SE}$ & $\mathrm{Chl} \pm \mathrm{SE}$ & $\mathrm{MDA} \pm \mathrm{SE}$ \\
\hline 12 & Oryzica 1 & $7.67 \pm 1.33$ & $0.40 \pm 0.19$ & $64.82 \pm 14.8$ & $8.17 \pm 4.30$ \\
\hline 13 & Quila 241313 & $2.00 \pm 0.00$ & $0.80 \pm 0.02$ & $205.7 \pm 21.6$ & $1.92 \pm 0.20$ \\
\hline 14 & Quila 194602 & $3.00 \pm 0.58$ & $0.81 \pm 0.02$ & $166.6 \pm 12.1$ & $1.74 \pm 0.08$ \\
\hline 15 & Quila 194603 & $3.33 \pm 0.33$ & $0.78 \pm 0.04$ & $175.8 \pm 27.3$ & $2.11 \pm 0.21$ \\
\hline 16 & Quila 200112 & $3.33 \pm 0.33$ & $0.76 \pm 0.02$ & $171.4 \pm 19.7$ & $2.68 \pm 0.24$ \\
\hline 17 & Quila 208902 & $4.00 \pm 0.58$ & $0.82 \pm 0.02$ & $111.6 \pm 54.9$ & $1.80 \pm 0.31$ \\
\hline 18 & Quila 213007 & $3.33 \pm 0.33$ & $0.80 \pm 0.01$ & $206.3 \pm 25.2$ & $1.85 \pm 0.16$ \\
\hline 19 & Quila 216202 & $3.67 \pm 0.67$ & $0.82 \pm 0.04$ & $162.9 \pm 42.0$ & $2.42 \pm 0.13$ \\
\hline 20 & Quila 216501 & $2.67 \pm 0.33$ & $0.84 \pm 0.00$ & $172.0 \pm 38.2$ & $2.05 \pm 0.12$ \\
\hline 21 & Quila 222204 & $2.33 \pm 0.67$ & $0.83 \pm 0.02$ & $167.1 \pm 18.1$ & $3.44 \pm 1.29$ \\
\hline 22 & Quila 222703 & $2.67 \pm 0.67$ & $0.83 \pm 0.02$ & $240.4 \pm 15.0$ & $2.29 \pm 0.20$ \\
\hline 23 & Quila 223105 & $2.67 \pm 0.33$ & $0.83 \pm 0.02$ & $193.8 \pm 38.2$ & $1.76 \pm 0.26$ \\
\hline 24 & Quila 223202 & $2.67 \pm 0.67$ & $0.85 \pm 0.01$ & $215.3 \pm 11.5$ & $1.81 \pm 0.25$ \\
\hline 25 & Quila 224802 & $2.33 \pm 0.33$ & $0.85 \pm 0.01$ & $191.8 \pm 31.6$ & $1.81 \pm 0.34$ \\
\hline 26 & Quila 225102 & $2.33 \pm 0.33$ & $0.85 \pm 0.00$ & $231.1 \pm 11.7$ & $1.89 \pm 0.28$ \\
\hline 27 & Quila 231701 & $2.33 \pm 0.33$ & $0.84 \pm 0.01$ & $193.7 \pm 35.9$ & $2.16 \pm 0.32$ \\
\hline 28 & Quila 240101 & $3.67 \pm 0.33$ & $0.82 \pm 0.02$ & $218.7 \pm 26.1$ & $3.07 \pm 0.27$ \\
\hline 29 & Quila 240103 & $4.00 \pm 0.58$ & $0.81 \pm 0.02$ & $184.2 \pm 48.6$ & $2.17 \pm 0.31$ \\
\hline 30 & Quila 240208 & $2.33 \pm 0.33$ & $0.83 \pm 0.01$ & $177.4 \pm 51.4$ & $1.69 \pm 0.29$ \\
\hline 31 & Quila 241304 & $1.67 \pm 0.33$ & $0.82 \pm 0.02$ & $279.6 \pm 20.4$ & $2.18 \pm 0.22$ \\
\hline 32 & Quila 241305 & $2.33 \pm 0.33$ & $0.83 \pm 0.02$ & $263.4 \pm 6.7$ & $1.91 \pm 0.20$ \\
\hline 33 & Quila 241307 & $3.00 \pm 0.00$ & $0.79 \pm 0.02$ & $149.6 \pm 42.4$ & $1.98 \pm 0.09$ \\
\hline 34 & Quila 241315 & $3.33 \pm 0.33$ & $0.82 \pm 0.01$ & $252.1 \pm 34.8$ & $2.91 \pm 0.90$ \\
\hline 35 & Quila 241319 & $2.67 \pm 0.33$ & $0.79 \pm 0.01$ & $226.5 \pm 15.8$ & $2.43 \pm 0.35$ \\
\hline 36 & Quila 241321 & $2.67 \pm 0.33$ & $0.81 \pm 0.01$ & $243.0 \pm 11.9$ & $1.68 \pm 0.29$ \\
\hline 37 & Quila 241605 & $3.00 \pm 0.00$ & $0.81 \pm 0.01$ & $242.7 \pm 38.5$ & $1.86 \pm 0.08$ \\
\hline 38 & Quila 241607 & $7.00 \pm 1.00$ & $0.83 \pm 0.01$ & $133.0 \pm 6.4$ & $3.48 \pm 0.94$ \\
\hline 39 & Quila 241610 & $3.00 \pm 0.00$ & $0.84 \pm 0.01$ & $174.1 \pm 39.3$ & $2.41 \pm 0.35$ \\
\hline 40 & Quila 241612 & $2.67 \pm 0.33$ & $0.85 \pm 0.01$ & $253.0 \pm 19.6$ & $1.89 \pm 0.31$ \\
\hline 41 & Quila 241701 & $1.67 \pm 0.33$ & $0.84 \pm 0.01$ & $217.3 \pm 35.9$ & $1.51 \pm 0.13$ \\
\hline 42 & Quila 241703 & $3.00 \pm 0.00$ & $0.84 \pm 0.01$ & $202.8 \pm 20.3$ & $2.26 \pm 0.34$ \\
\hline 43 & Quila 241801 & $4.00 \pm 0.58$ & $0.82 \pm 0.01$ & $130.2 \pm 29.5$ & $2.60 \pm 0.38$ \\
\hline 44 & Quila 242002 & $2.67 \pm 0.33$ & $0.85 \pm 0.01$ & $295.3 \pm 60.2$ & $2.13 \pm 0.34$ \\
\hline 45 & Quila 242003 & $3.33 \pm 0.33$ & $0.83 \pm 0.01$ & $256.3 \pm 36.5$ & $2.26 \pm 0.37$ \\
\hline 46 & Quila 242006 & $2.67 \pm 0.33$ & $0.83 \pm 0.02$ & $230.7 \pm 7.3$ & $1.65 \pm 0.37$ \\
\hline 47 & Quila 242007 & $2.67 \pm 0.67$ & $0.83 \pm 0.01$ & $179.4 \pm 26.2$ & $5.57 \pm 3.86$ \\
\hline 48 & Quila 242010 & $3.33 \pm 0.33$ & $0.81 \pm 0.03$ & $223.0 \pm 11.5$ & $2.05 \pm 0.45$ \\
\hline 49 & Quila 242011 & $2.67 \pm 1.67$ & $0.82 \pm 0.02$ & $212.3 \pm 56.1$ & $1.86 \pm 0.13$ \\
\hline 50 & Quila 242012 & $3.00 \pm 0.58$ & $0.80 \pm 0.02$ & $193.8 \pm 21.7$ & $2.32 \pm 0.12$ \\
\hline 51 & Quila 242101 & $2.67 \pm 0.33$ & $0.84 \pm 0.01$ & $191.6 \pm 34.8$ & $1.48 \pm 0.26$ \\
\hline 52 & Quila 242106 & $2.67 \pm 0.33$ & $0.79 \pm 0.03$ & $173.1 \pm 28.2$ & $2.39 \pm 0.05$ \\
\hline 53 & Quila 242108 & $3.33 \pm 0.33$ & $0.83 \pm 0.01$ & $183.0 \pm 47.9$ & $2.11 \pm 0.33$ \\
\hline 54 & Quila 242112 & $3.00 \pm 0.00$ & $0.83 \pm 0.02$ & $177.2 \pm 35.1$ & $1.96 \pm 0.18$ \\
\hline 55 & Quila 242114 & $3.00 \pm 0.58$ & $0.83 \pm 0.02$ & $237.6 \pm 37.7$ & $2.21 \pm 0.23$ \\
\hline 56 & Quila 242115 & $2.33 \pm 0.33$ & $0.84 \pm 0.01$ & $250.3 \pm 23.8$ & $1.95 \pm 0.07$ \\
\hline 57 & Quila 242121 & $3.00 \pm 0.00$ & $0.83 \pm 0.00$ & $202.6 \pm 25.7$ & $2.30 \pm 0.59$ \\
\hline 58 & Quila 242203 & $3.00 \pm 0.00$ & $0.83 \pm 0.01$ & $204.9 \pm 37.6$ & $3.03 \pm 0.43$ \\
\hline 59 & Quila 242204 & $3.67 \pm 0.33$ & $0.82 \pm 0.03$ & $164.3 \pm 23.0$ & $2.58 \pm 0.43$ \\
\hline 60 & Quila 242207 & $2.33 \pm 0.33$ & $0.82 \pm 0.03$ & $210.4 \pm 30.4$ & $1.91 \pm 0.15$ \\
\hline 61 & Quila 242415 & $2.67 \pm 0.33$ & $0.83 \pm 0.01$ & $249.8 \pm 8.0$ & $2.42 \pm 0.19$ \\
\hline 62 & Quila 242420 & $2.67 \pm 0.33$ & $0.83 \pm 0.01$ & $244.4 \pm 8.3$ & $1.81 \pm 0.21$ \\
\hline 63 & Quila 242504 & $3.00 \pm 0.00$ & $0.82 \pm 0.01$ & $204.7 \pm 31.0$ & $1.86 \pm 0.28$ \\
\hline 64 & Quila 242608 & $4.33 \pm 0.88$ & $0.80 \pm 0.02$ & $145.7 \pm 26.9$ & $2.27 \pm 0.20$ \\
\hline 65 & Quila 242609 & $3.33 \pm 0.33$ & $0.83 \pm 0.01$ & $202.2 \pm 23.3$ & $2.13 \pm 0.28$ \\
\hline 66 & Quila 242610 & $3.00 \pm 0.00$ & $0.82 \pm 0.01$ & $200.6 \pm 27.4$ & $2.16 \pm 0.32$ \\
\hline 67 & Quila 242612 & $3.00 \pm 0.58$ & $0.77 \pm 0.07$ & $190.8 \pm 20.0$ & $2.26 \pm 0.53$ \\
\hline 68 & Quila 242613 & $4.00 \pm 1.00$ & $0.79 \pm 0.01$ & $189.2 \pm 38.7$ & $2.28 \pm 0.44$ \\
\hline 69 & Quila 242616 & $3.33 \pm 0.33$ & $0.84 \pm 0.00$ & $204.3 \pm 29.0$ & $2.36 \pm 0.30$ \\
\hline 70 & Quila 242701 & $3.00 \pm 0.58$ & $0.83 \pm 0.02$ & $200.8 \pm 12.8$ & $2.20 \pm 0.19$ \\
\hline
\end{tabular}


Cold tolerance evaluation in temperate rice seedling: Donoso, G. ET AL.

\begin{tabular}{|c|c|c|c|c|c|}
\hline $\mathrm{N}^{\circ}$ & GENOTYPE & $\mathrm{SES} \pm \mathrm{SE}$ & $\mathrm{Fv} / \mathrm{Fm} \pm \mathrm{SE}$ & $\mathrm{Chl} \pm \mathrm{SE}$ & $\mathrm{MDA} \pm \mathrm{SE}$ \\
\hline 71 & Quila 242703 & $3.33 \pm 0.33$ & $0.83 \pm 0.02$ & $194.2 \pm 36.3$ & $2.26 \pm 0.07$ \\
\hline 72 & Quila 242802 & $3.00 \pm 0.58$ & $0.82 \pm 0.03$ & $170.7 \pm 35.3$ & $2.57 \pm 0.39$ \\
\hline 73 & Quila 242808 & $3.00 \pm 0.58$ & $0.84 \pm 0.01$ & $130.3 \pm 35.4$ & $2.72 \pm 0.87$ \\
\hline 74 & Quila 243008 & $2.67 \pm 0.33$ & $0.82 \pm 0.00$ & $190.1 \pm 27.0$ & $2.36 \pm 0.54$ \\
\hline 75 & Quila 243010 & $2.00 \pm 1.00$ & $0.83 \pm 0.01$ & $192.0 \pm 21.4$ & $1.93 \pm 0.31$ \\
\hline 76 & Quila 244013 & $3.33 \pm 0.33$ & $0.86 \pm 0.00$ & $201.5 \pm 25.7$ & $1.41 \pm 0.16$ \\
\hline 77 & Quila 249002 & $3.00 \pm 0.00$ & $0.85 \pm 0.01$ & $176.3 \pm 21.1$ & $2.60 \pm 0.43$ \\
\hline 78 & Quila 249006 & $4.33 \pm 0.33$ & $0.83 \pm 0.01$ & $190.0 \pm 20.2$ & $1.83 \pm 0.22$ \\
\hline 79 & Quila 249101 & $2.67 \pm 0.33$ & $0.84 \pm 0.00$ & $230.8 \pm 24.6$ & $2.45 \pm 0.31$ \\
\hline 80 & Quila 249103 & $3.00 \pm 0.58$ & $0.84 \pm 0.01$ & $191.3 \pm 51.0$ & $1.76 \pm 0.24$ \\
\hline 81 & Quila 249104 & $3.00 \pm 0.00$ & $0.82 \pm 0.01$ & $143.8 \pm 60.4$ & $2.29 \pm 0.55$ \\
\hline 82 & Quila 249203 & $3.33 \pm 0.88$ & $0.84 \pm 0.00$ & $228.6 \pm 17.6$ & $1.89 \pm 0.47$ \\
\hline 83 & Quila 249301 & $3.33 \pm 0.88$ & $0.83 \pm 0.02$ & $186.7 \pm 37.2$ & $3.47 \pm 1.40$ \\
\hline 84 & Quila 249303 & $2.67 \pm 0.33$ & $0.82 \pm 0.02$ & $245.3 \pm 15.8$ & $2.15 \pm 0.18$ \\
\hline 85 & Quila 249304 & $3.33 \pm 1.45$ & $0.84 \pm 0.01$ & $219.6 \pm 46.9$ & $2.39 \pm 0.50$ \\
\hline 86 & Quila 251303 & $3.33 \pm 0.88$ & $0.83 \pm 0.02$ & $158.5 \pm 40.9$ & $1.86 \pm 0.37$ \\
\hline 87 & Quila 252201 & $3.67 \pm 0.33$ & $0.83 \pm 0.01$ & $187.3 \pm 27.5$ & $2.20 \pm 0.45$ \\
\hline 88 & Quila 252702 & $4.00 \pm 1.00$ & $0.83 \pm 0.01$ & $164.2 \pm 66.1$ & $2.28 \pm 0.29$ \\
\hline 89 & Quila 252801 & $3.33 \pm 0.33$ & $0.78 \pm 0.06$ & $158.8 \pm 45.4$ & $2.60 \pm 0.27$ \\
\hline 90 & Quila 253003 & $2.67 \pm 0.33$ & $0.82 \pm 0.01$ & $180.7 \pm 34.2$ & $1.67 \pm 0.10$ \\
\hline 91 & Quila 253701 & $2.33 \pm 0.33$ & $0.83 \pm 0.02$ & $178.4 \pm 21.8$ & $2.08 \pm 0.16$ \\
\hline 92 & Quila 254101 & $4.00 \pm 1.00$ & $0.82 \pm 0.02$ & $191.1 \pm 47.9$ & $2.30 \pm 0.17$ \\
\hline 93 & Quila 254701 & $4.00 \pm 1.15$ & $0.79 \pm 0.04$ & $130.1 \pm 17.5$ & $1.40 \pm 0.11$ \\
\hline 94 & Quila 256001 & $4.33 \pm 1.20$ & $0.82 \pm 0.01$ & $121.7 \pm 57.9$ & $2.02 \pm 0.30$ \\
\hline 95 & Quila 256002 & $2.33 \pm 0.33$ & $0.82 \pm 0.02$ & $192.4 \pm 18.8$ & $1.85 \pm 0.17$ \\
\hline 96 & Quila 256101 & $2.33 \pm 0.33$ & $0.85 \pm 0.01$ & $247.3 \pm 19.7$ & $1.78 \pm 0.21$ \\
\hline 97 & Quila 256103 & $2.67 \pm 0.33$ & $0.82 \pm 0.01$ & $190.4 \pm 34.8$ & $2.20 \pm 0.20$ \\
\hline 98 & Quila 256104 & $2.67 \pm 0.33$ & $0.83 \pm 0.01$ & $184.5 \pm 19.7$ & $1.75 \pm 0.26$ \\
\hline 99 & Quila 256106 & $2.67 \pm 0.67$ & $0.79 \pm 0.04$ & $236.8 \pm 20.6$ & $2.33 \pm 0.43$ \\
\hline 100 & Quila 256501 & $3.33 \pm 0.33$ & $0.82 \pm 0.03$ & $193.7 \pm 26.2$ & $2.15 \pm 0.13$ \\
\hline 101 & Quila 256601 & $1.67 \pm 0.67$ & $0.84 \pm 0.02$ & $183.7 \pm 17.1$ & $1.79 \pm 0.14$ \\
\hline 102 & Quila 256602 & $3.33 \pm 0.33$ & $0.82 \pm 0.01$ & $181.0 \pm 12.5$ & $1.89 \pm 0.05$ \\
\hline 103 & Quila 256603 & $2.67 \pm 0.33$ & $0.83 \pm 0.01$ & $163.4 \pm 29.3$ & $2.19 \pm 0.28$ \\
\hline 104 & Quila 256701 & $2.67 \pm 0.33$ & $0.83 \pm 0.01$ & $227.6 \pm 18.2$ & $2.70 \pm 0.88$ \\
\hline 105 & Quila 256901 & $2.33 \pm 0.33$ & $0.80 \pm 0.02$ & $171.6 \pm 44.7$ & $1.61 \pm 0.07$ \\
\hline 106 & Quila 260312 & $7.33 \pm 0.33$ & $0.75 \pm 0.05$ & $114.6 \pm 54.5$ & $2.80 \pm 0.29$ \\
\hline 107 & Quila 260404 & $3.00 \pm 0.00$ & $0.82 \pm 0.02$ & $187.6 \pm 40.1$ & $1.99 \pm 0.17$ \\
\hline 108 & Quila 64117 & $5.67 \pm 0.87$ & $0.66 \pm 0.07$ & $102.5 \pm 27.2$ & $5.51 \pm 2.73$ \\
\hline 109 & RQuila 17 & $3.00 \pm 0.00$ & $0.84 \pm 0.01$ & $174.5 \pm 26.6$ & $2.65 \pm 0.23$ \\
\hline 110 & Rquila 356 & $2.33 \pm 0.67$ & $0.83 \pm 0.02$ & $181.3 \pm 39.1$ & $2.00 \pm 0.19$ \\
\hline 111 & RQuila 363 & $3.00 \pm 0.58$ & $0.82 \pm 0.01$ & $182.5 \pm 42.6$ & $2.05 \pm 0.21$ \\
\hline
\end{tabular}

Recibido: 01.08.14

Aceptado: 26.08.14 